\title{
A PILOT STUDY TO ASSESS KIDNEY FUNCTIONS AND TOXIC DIMETHYL-ARGININES AS RISK BIOMARKERS IN WOMEN WITH LOW VITAMIN D LEVELS
}

\author{
PILOT IZUČAVANJE BUBREŽNE FUNKCIJE I TOKSIČNOSTI DIMETIL-ARGININA \\ KAO RIZIČNOG BIOMARKERA U ŽENA SA NISKIM NIVOIMA VITAMINA D
}

\author{
Samar Damiati \\ Department of Biochemistry, Faculty of Science, King Abdulaziz University (KAU), Jeddah, Saudi Arabia
}

\begin{abstract}
Summary
Background: Although vitamin D in not a traditional marker for cardiovascular and renal diseases, several studies have proposed a correlation between vitamin D deficiency and these diseases due to the effect of vitamin D on endothelial function. Asymmetric and symmetric dimethyl arginine (ADMA and SDMA, respectively) are endogenous markers of endothelial dysfunction, and are considered as future markers for the assessment of cardiovascular and renal diseases. The present study investigated the association of kidney function tests (urea and creatinine) and dimethylarginine toxins (ADMA and SDMA) in women with vitamin $D$ insufficiency or deficiency. Indeed, sex hormones (estrogen and testosterone) were analyzed in the participants.

Methods: Women were divided into two groups: premenopausal women (younger than 50 years) and postmenopausal women (older than 50 years). Urea, creatinine, estrogen, testosterone, ADMA, and SDMA levels were analyzed when vitamin $D$ level was deficient or insufficient in the participants.
\end{abstract}

Results: The premenopausal women group showed no significant correlations between dimethylarginine toxins and renal failure tests or sex hormones. In the elderly (postmenstrual) women group, only SDMA was significantly correlated with urea and creatinine, while both ADMA and SDMA were not correlated with sex hormones.

Conclusions: Although ADMA and SDMA are promising candidates of endothelial dysfunction and are increased in menopause and aging, no direct link between ADMA and further progression of renal failure was observed in women with low vitamin D levels. In contrast, a possible direct cor-

\begin{abstract}
Kratak sadržaj
Uvod: Mada vitamin D nije tradicionalni marker kardiovaskularnih i bubrežnih oboljenja, nekoliko izučavanja ukazuje na korelaciju između deficita vitamina D i ovih oboljenja zbog uticaja vitamina $D$ na endotelijalnu funkciju. Asimetrični i simetrični dimetil arginin (ADMA, odnosno SDMA) su endogeni markeri endotelijalne disfunkcije, i mogu se smatrati kao budući markeri za procenu kardiovaskularnih i bubrežnih oboljenja. U ovom radu izučavana je veza između testova za ispitivanje funkcije bubrega (ureja i kreatinin) i dimetilarginin toksina (ADMA i SDMA) u žena sa insuficijencijom ili deficitom vitamina D. Osim toga izučavani su polni hormoni (estrogen $\mathrm{i}$ testosteron) kod ovih ispitanica.

Metode: Žene su podeljenje u dve grupe: premenopauzalne žene (mlađe od 50 godina) i postmenopauzalne žene (starije od 50 godina). Analizirani su nivoi ureje, kreatinina, estrogena, testosterona, ADMA i SDMA, kada su nivoi vitamina D bili deficijentni ili insuficijentni kod ispitanica.

Rezultati: Nije nađena značajna korelacija u grupi premenopauzalnih žena između dimetilarginin toksina i testova bubrežne funkcije ili polnih hormona. U starijih žena (postmenopauzalne), samo je SDMA bila u značajnoj koralaciji sa urejom i kreatininom, dok ADMA i SDMA nisu bile u korelaciji sa polnim hormonima.

Zaključak: Mada su ADMA i SDMA obećavajući kandidati endotelijalne disfunkcije i povećavaju se u menopauzi i starenjem, nije nađena direktna veza između ADMA i daljeg progresa renalnog oštećenja $u$ žena sa niskim nivoima vitamina D. Suprotno ovome, uočena je moguća direktna korelacija između SDMA i renalne disfunkcije, mada jedino zavisno od starosnog doba.
\end{abstract}

Address for correspondence:

Samar Damiati

Department of Biochemistry, Faculty of Science

King Abdulaziz University (KAU), Jeddah, SA

e-mail: sdamiati@kau.edu.sa 
relation between SDMA and renal dysfunction was noticed, but only in an age-dependent manner.

Keywords: asymmetric and symmetric dimethyl arginine, renal dysfunction, vitamin $D$ deficiency, sex hormones, endothelial markers

\section{Introduction}

The association of chronic renal disease with cardiovascular disease is a world health problem that is considered as a fetal complication. It has been reported that patients with chronic renal disease have higher risk of cardiovascular disease and suffer from accelerated atheromatosis (1-3). For example, in young dialysis patients (aged between 25 and 35 years), cardiovascular mortality risk is increased $\sim 375$ times, while elderly dialysis patients ( $>75$ years) have a five-fold higher cardiovascular mortality risk (4). A relationship between gender and chronic kidney disease (CKD) was also addressed; CKD is more severe in men, while the prevalence is higher in women. Several factors may cause gender to influence the risk of CKD. Pounds et al. (5) assumed that since muscle mass and creatinine generation levels are higher in men than women, men have higher levels of kidney function, which may be linked to the severity of the disease in men. Another factor is nitric oxide (NO) level, which is influenced by sex hormones and has a complex role in renal injury (6). Estrogen plays a significant role in lowering the kidney oxidative stress by suppressing the activity of NADPH oxidase, while the depletion of estrogen is associated with the reduction of NO synthesis and leads to endothelial dysfunction (7). Estradiol also has an inhibitory effect on endothelin synthesis, as well as its vasoconstriction and inflammation effect (8). Additionally, the renin-angiotensin system is stimulated by testosterone and suppressed by estrogen (8).

Asymmetric and symmetric dimethyl arginine (ADMA and SDMA, respectively) are metabolites of arginine that are synthesized from the proteolysis of methylated proteins (9). ADMA is an endogenous inhibitor of NO synthase (NOS) that is mainly metabolized by the enzyme dimethylarginine dimethylamino-hydrolase (DDAH) to citrullin and dimethylamine, or eliminated from the body by renal excretion $(9,10)$. Elevated levels of ADMA reduce NO synthesis, which causes endothelial dysfunction and may contribute to the progression of vascular disease. Hence, the direct effect of ADMA on endothelial damage presents ADMA as a predictor of cardiovascular risk (11-13). In contrast, SDMA is exclusively eliminated by renal excretion. Moreover, SDMA has an indirect (or weak) effect on NOS activity by restricting the availability of arginine to NOS and competing for the transportation of arginine $(10,12,14)$. SDMA is considered as an early marker of renal dysfunction.
Ključne reči: asimetrični $\mathrm{i}$ simetrični dimetil arginin, renalna disfunkcija, deficijencija vitamina $D$, polni hormoni, endotelni markeri

Fliser et al. (15) reported a close correlation among SDMA, creatinine, and glamor filtration rate (GFR), and suggested that the SDMA level is equal to the serum creatinine level. However, it has been assumed that both ADMA and SDMA may interfere with the physiological defense mechanism in patients with $C K D$, which leads to the accumulation of these two compounds. Hence, both ADMA and SDMA are considered as uremic toxins (16-19).

Several studies linked vitamin $D$ deficiency and ADMA, either in general (20) or elderly (21) populations. Low level of vitamin $D$ was correlated inversely with ADMA level, and an association between seasonal fluctuation of vitamin $D$ and fluctuation of ADMA was found (20). In patients with CKD at stage $G 5 D$, an inverse relationship between vitamin $D$ and ADMA was reported (22). Vitamin D deficiency is also associated with atherosclerosis cardiovascular disease, which may be mediated by the action of sex hormones (estrogen and testosterone) (23). Since vitamin $D$ plays a significant role in endothelial function/dysfunction, this study was designed to estimate the correlation between kidney function and dimethylarginine toxins by measuring urea, creatinine, ADMA, and SDMA in women suffering from vitamin $D$ insufficiency/deficiency in premenopausal and postmenopausal women. It is also aimed to determine whether the association between the menstruation and dimethyl arginine compounds was influenced by sex hormones, and whether these markers can be used further as early markers of renal dysfunction when low vitamin $D$ level is a common factor in both groups.

\section{Materials and Methods}

\section{Participants}

In this study, all participants were women aged between 17 and 73 years suffering from vitamin $D$ insufficiency or deficiency $(75-125$ or $<75 \mathrm{nmol} / \mathrm{L}$, respectively), and without any cardiac or renal complications. Women were divided into two groups: Group I consisted of young premenopausal women $(n=42)$ aged below 50 years, and Group II consisted of elderly postmenopausal women $(n=39)$ aged above 50 years. After fasting for approximately 8 hours, blood samples were collected and centrifuged at $3000 \mathrm{rpm}$ for $10 \mathrm{~min}$. Serum samples were stored at $-20^{\circ} \mathrm{C}$ until further investigations. 


\section{Ethics approval and consent to participate}

The ethical approval was obtained from Biomedical Ethics Unit, King Abdulaziz University (Ref. no. 915). After invitation, all invited women who agreed to participate in the study signed a written consent form.

\section{Biochemical Markers}

Serum ADMA and SDMA levels were estimated using commercial ELISA kits (DLD Diagnostika, Germany). Vitamin D (25(OH)D) level was measured by direct competitive chemiluminescence kit (Siemens, US). Sex hormones, urea, creatinine, glucose, and lipid profile were measured by commercially available immunoassays (Roche Diagnostics, Germany, or Ortho Clinical Diagnostics, US).

\section{Statistical Analysis}

Statistical Package for the Social Science (SPSS, version 22) was used in this study. Results are expressed as mean \pm standard deviation (SD). The correlations between various parameters were assessed by the Pearson correlation coefficient.

\section{Results}

The clinical characteristics of the participants in this study are presented in Table I. All women who participated in this study had deficient or insufficient in vitamin $D$ levels and were divided into two groups: premenopausal women (younger than 50 years) and postmenopausal women (older than 50 years). The
Table I Biochemical characteristics of study population. Results are presented as means \pm SD ( $P<0.001,{ }^{* *} P<$ 0.01).

\begin{tabular}{|l|c|c|}
\hline & $\begin{array}{c}\text { Premenopausal } \\
\text { Women }(\mathrm{n}=42)\end{array}$ & $\begin{array}{c}\text { Postmenopausal } \\
\text { Women }(\mathrm{n}=39)\end{array}$ \\
\hline Age $($ Years $)$ & $33.95 \pm 8.57$ & $58.95 \pm 5.83 *$ \\
\hline BMI $\left(\mathrm{kg} / \mathrm{m}^{2}\right)$ & $28.19 \pm 7.83$ & $34.50 \pm 11.20^{* *}$ \\
\hline SBP $(\mathrm{mmHg})$ & $106.61 \pm 50.89$ & $124.47 \pm 46.29$ \\
\hline DBP $(\mathrm{mmHg})$ & $70.67 \pm 30.80$ & $66.56 \pm 24.77$ \\
\hline Glucose $(\mathrm{mmol} / \mathrm{L})$ & $5.38 \pm 0.90$ & $5.32 \pm 1.40$ \\
\hline Cholesterol $(\mathrm{mmol} / \mathrm{L})$ & $4.24 \pm 0.99$ & $4.60 \pm 1.26$ \\
\hline TAG $(\mathrm{mmol} / \mathrm{L})$ & $1.38 \pm 0.54$ & $1.44 \pm 0.60$ \\
\hline $\begin{array}{l}\text { Vitamin D } \\
(25(O H) D),(\mathrm{nmol} / \mathrm{L})\end{array}$ & $57.20 \pm 33.52$ & $56.93 \pm 34.90$ \\
\hline Urea $(\mathrm{mmol} / \mathrm{L})$ & $3.29 \pm 1.50$ & $4.98 \pm 1.76 * *$ \\
\hline Creatinine $(\mu \mathrm{mol} / \mathrm{L})$ & $55.18 \pm 13.09$ & $65.49 \pm 17.94 * *$ \\
\hline Estrogen $(\mathrm{pg} / \mathrm{mL})$ & $268.13 \pm 275.40$ & $61.63 \pm 71 \pm 94 *$ \\
\hline Testosterone $(\mathrm{ng} / \mathrm{mL})$ & $1.60 \pm 2.20$ & $1.05 \pm 0.71$ \\
\hline ADMA $(\mu \mathrm{mol} / \mathrm{L})$ & $0.698 \pm 0.13$ & $0.764 \pm 0.19$ \\
\hline SDMA $(\mu \mathrm{mol} / \mathrm{L})$ & $0.618 \pm 0.14$ & $0.677 \pm 0.15$ \\
\hline
\end{tabular}

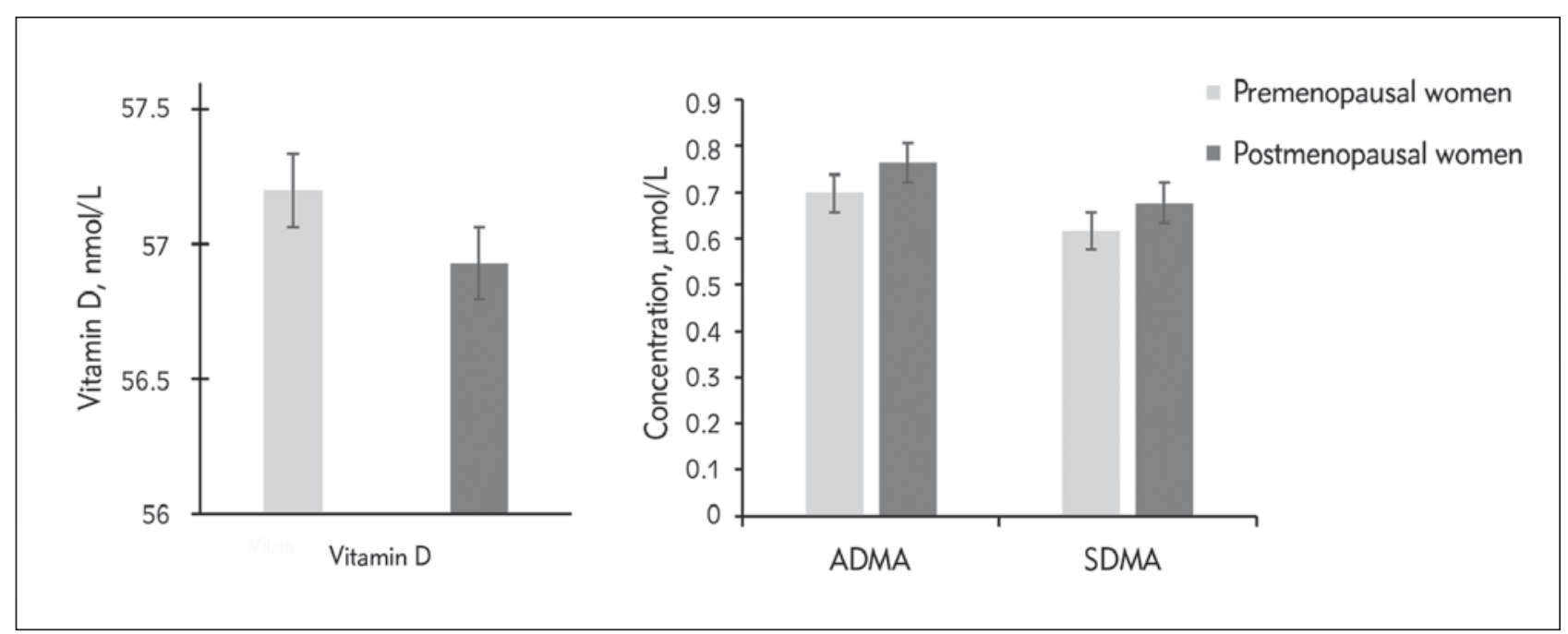

Figure 1 Concentrations of vitamin D, asymmetric and symmetric dimethyl arginine (ADMA and SDMA, respectively) in premenopausal and postmenopausal women. 


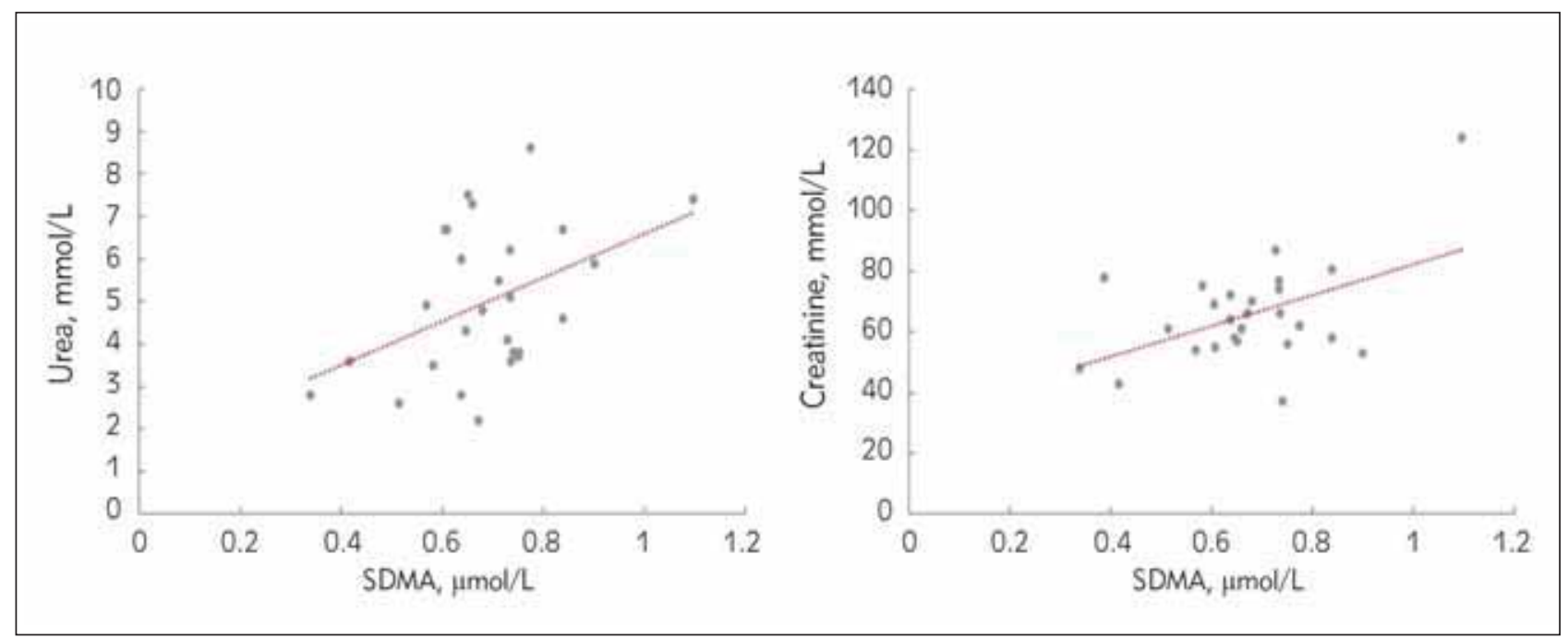

Figure 2 Correlation between SDMA and urea $(P<0.05)$, and between SDMA and creatinine $(P<0.01)$ in premenopausal or postmenopausal women.

Table II Correlation coefficient of serum ADMA and SDMA with various variables in women with vitamin D deficiency.

\begin{tabular}{|c|c|c|c|c|c|c|c|c|}
\hline \multirow{3}{*}{ Variable } & \multicolumn{4}{|c|}{ Premenopausal women $(n=42)$} & \multicolumn{4}{|c|}{ Postmenopausal women $(n=39)$} \\
\hline & \multicolumn{2}{|c|}{ ADMA } & \multicolumn{2}{|c|}{ SDMA } & \multicolumn{2}{|c|}{ ADMA } & \multicolumn{2}{|c|}{ SDMA } \\
\hline & $r$ & $\mathrm{p}$ & $r$ & $\mathrm{p}$ & $r$ & $\mathrm{p}$ & $r$ & $\mathrm{p}$ \\
\hline Age & 0.247 & 0.060 & 0.169 & 0.182 & -0.048 & 0.399 & -0.077 & 0.348 \\
\hline $\mathrm{BMI}$ & $0.486 * *$ & 0.003 & -0.078 & 0.342 & -0.117 & 0.289 & -0.236 & 0.123 \\
\hline Vitamin D & 0.028 & 0.447 & -0.064 & 0.379 & -0.310 & 0.080 & -0.044 & 0.422 \\
\hline Urea & 0.039 & 0.414 & -0.242 & 0.128 & 0.065 & 0.377 & $0.433^{*}$ & 0.012 \\
\hline Creatinine & 0.009 & 0.477 & -0.024 & 0.451 & 0.068 & 0.368 & $0.554^{* *}$ & 0.003 \\
\hline Estrogen & -0.146 & 0.264 & -0.074 & 0.374 & -0.025 & -0.028 & 0.285 & 0.112 \\
\hline Testosterone & 0.258 & 0.136 & 0.235 & 0.159 & 0.456 & 0.448 & 0.096 & 0.339 \\
\hline ADMA & - & - & -0.052 & 0.391 & - & - & -0.154 & 0.222 \\
\hline
\end{tabular}

**Correlation is significant at the 0.01 level.

*Correlation is significant at the 0.05 level.

measured variables of age and BMI were statically significant, while systolic blood pressure (SBP), diastolic blood pressure (DBP), glucose, cholesterol, triacylglycerol (TAG), and vitamin D were statically insignificant between women younger and older than 50 years. Concentrations of urea and creatinine were significantly lower in young women compared to older participants $(P<0.001)$. As expected, sex hormones were higher in young women compared to older participants. Estrogen levels were significantly higher in young women than older women $(268.13 \pm 275.40$ vs $61.63 \pm 71 \pm 94 \mathrm{pg} / \mathrm{mL}, P<0.001)$ while testos- terone levels were statically meaningless for younger and older women. Serum concentrations of ADMA and SDMA were lower in premenopausal women, but exhibited no significant differences between the two groups (Figure 1). Indeed, ADMA showed higher levels than SDMA in both groups.

To find a link with vitamin D, the correlation between kidney function test and dimethylarginine toxins was investigated. In both groups of women, premenopausal or postmenopausal, suffering from vitamin D insufficiency/deficiency, no correlation was 
found between vitamin D levels and kidney function tests (urea and creatinine), sex hormones (estrogen and testosterone), or dimethylarginine toxins (ADMA and SDMA). In young women, BMI was significantly positively correlated with age, urea, and ADMA. Testosterone was significantly positively correlated with creatinine $(r=0.616, P<0.01)$, and significantly negatively correlated with age $(r=-0.464, P$ $<0.05)$. In contrast, older women showed significant correlations between the following: a positive correlation was found between SDMA and urea $(r=0.433$, $P<0.05)$, as well as between SDMA and creatinine $(r=0.554, P<0.01)$ (Figure 2$)$, and BMI was positively correlated with estrogen $(r=0.575, P<0.01)$. Table II shows the correlations between ADMA or SDMA with various variables measured in this study.

\section{Discussion}

In this study, markers of kidney functions (urea and creatinine) and endothelial dysfunction (ADMA and SDMA) were assessed in women suffering from vitamin D insufficiency or deficiency. Several studies have shown a link between hypovitaminosis $D$ and the progression of CKD $(24,25)$. Moreover, SDMA, but not ADMA, has been considered as an early marker of renal disease (26). The obtained results showed significantly higher concentrations of urea and creatinine, and non-significantly higher concentrations of ADMA and SDMA in women above 50 years of age (postmenopausal) compared to women below 50 years of age (premenopausal). Several publications have shown that aging/menopausal status has an effect on several factors associated with cardiovascular risk and renal failure, such as cholesterol, TAG, urea, and creatinine. Beside these factors, ADMA and SDMA are considered as predictor markers for cardiovascular and kidney diseases, respectively (27). However, in this work, when all participants exhibited low levels of vitamin D, no significant link between ADMA and risk factors of renal failure was confirmed, while SDMA significantly correlated with urea and creatinine in postmenopausal women. Hence, this finding confirms the link between SDMA and renal failure in elderly populations, and may illustrate a direct link that will enable us to consider SDMA as a future predictor of renal dysfunction.

Age- and sex-dependent differences were found in ADMA levels. Men younger than 50 years have higher ADMA levels than women in the same age group, while older women have higher ADMA than men older than 50 years $(28,29)$. By assuming that 50 years of age is approximately the age of onset of menopause in women $(30,31)$, it has been shown that ADMA levels increased with the onset of menopause, which may be attributed to changes in sex hormones concentrations as an important factor in the menstrual cycle (32). Since estrogen enhances NO synthesis and reduces ADMA synthesis, exoge- nous estrogen was able to reduce ADMA levels in postmenopausal women (33). Holden et al. (34) reported that exposing cultured cells to 17-estradiol decreased ADMA levels in a dose-dependent manner, but did not decrease SDMA, by increasing DDAH activity with increasing 17-estradiol concentration in the medium. Moreover, Valtonen et al. (35) reported the differences between natural and synthetic steroids and their impact on ADMA and SDMA levels in women during the menstrual cycle. In non-oral contraceptive users, there was significant differences between ADMA levels during different menstrual cycle phases, while SDMA did not show any differences across the menstrual cycle. This observation may indicate that SDMA is not sensitive to hormonal changes because it is excreted from the body by renal excretion and not metabolized by DDAH. In oral contraceptive users, circulating ADMA and SDMA levels decreased significantly in women using an oral contraceptive containing estrogen in comparison to women not taking an oral contraceptive. With respect to previous studies, the obtained results in the present study showed that women younger than 50 years had significantly higher estrogen and non-significantly higher testosterone concentrations and non-significantly lower arginine derivatives (ADMA and SDMA) compared to older women, which is expected while taking into consideration that both groups are suffering from vitamin D insufficiency/deficiency.

Body weight is also influenced by sex-gender differences. Campsei et al. (36) showed that, before body weight correction, premenopausal women had significantly elevated levels of total cholesterol, TAG, and creatinine compared to postmenopausal women. After body weight correction, differences in creatinine concentrations disappeared, while concentrations of total cholesterol and TAG were maintained at high levels in postmenopausal women. In contrast, in men, results before and after body correction did not change. However, in the same study, ADMA and SDMA levels were lower in women than in men younger than 45 years before body weight correction and there was no difference after body weight correction between the two groups. In contrast, before body weight correction, there was no difference in ADMA and SDMA levels between men and women older than 45 years, but after correcting the body weight, women had higher levels.

The direct link between vitamin D and endothelial dysfunction, heart or kidney diseases has been assessed in several studies. The mechanism of how vitamin D impacts endothelial dysfunction is not yet comprehensibly studied. Hence, it is important to find the link between vitamin D and ADMA or SDMA, since these two biomarkers directly or indirectly influence the level of $\mathrm{NO}$ which increases the risk of endothelial dysfunction in different diseases. It has been noticed that dimethylarginine levels tend to fluctuate in the same disease (37-41). Several factors 
influence ADMA circulating levels, such as gene polymorphism, age, sex, BMI, season, and diet $(21,42)$. $\mathrm{Ngo}$ et al. (43) reported the fluctuation levels of ADMA. They found that ADMA was inversely correlated with seasonal fluctuation in vitamin D concentrations. In contrast, not enough information has been reported on the factors that influence SDMA levels. However, SDMA concentration is not influenced by the dietary content of arginine, because it is derived from methylated nuclear proteins (44).

Various ethnicities and various frequencies of polymorphisms of vitamin $D$ may impact ADMA and SDMA levels in different studies. Chitalia et al. (45) reported a direct link between deficiency of vitamin $D$ and endothelial dysfunction in patients with mild to moderate chronic kidney disease. In contrast, Maaty et al. (42) found a non-significant correlation between vitamin $D, A D M A$, and SDMA, wherein vitamin D activated the NO system but had no effect on endothelial dysfunction. Several drugs, such as enalapril (46), perindopril (47), and zofenopril (48), have shown an effect on ADMA by reducing the circulating level. However, these drugs may interfere with the role of ADMA and SDMA in NO synthesis in cardiovascular or renal diseases. Oliva-Damaso et al. (49) reported on treated hemodialysis patients using paricalcitol, a vitamin $D$ analogue. In patients with $C K D$, paricalcitol may offer a survival benefit by reducing $A D M A$ levels. It is possible that the antioxidant effect of vitamin $D$ may reduce the lipid peroxidation and enhance endothelial function (50). Since the antioxidant activity improves the activity of DDAH and lowers the activity of type 1 protein arginine methyltransferase (PRMT), it reduces ADMA synthesis and activates its degradation $(51,52)$.

Although ADMA is not directly correlated with the parameters of renal failure, it causes endothelial dysfunction, which may contribute to renal disease. However, there is an explanation of why ADMA is linked to parameters of renal failure in some studies. It is well-known that ADMA is metabolized by the degradation action of DDAH, which present in the kidney at high concentrations. If there is a renal impairment that leads to a decline in DDAH activity and a reduction of renal excretory function, this results in an accumulation of ADMA in the body (53). Indeed, in patients with chronic renal failure, ADMA is considered as a future marker of mortality and cardiovascular disease (49). SDMA was confirmed as an endogenous marker of renal failure that correlated directly with parameters of renal failure $(53,54)$. After total nephrectomy in a rat model, the circulating level of SDMA increased rapidly in parallel with blood urea nitrogen and creatinine (55). SDMA can indirectly affect NO synthesis by two mechanisms that depend on interfering with the intracellular uptake of arginine: either by inhibiting renal tubular arginine absorption or by inhibiting the $y+$ transporter (56, 57). Kielstein et al. (58) presented SDMA as an early marker to detect acute kidney injury by indicating the changes in the GFR. However, SDMA is sometimes more sensitive than creatinine in the detection of renal dysfunction (53). Hence, Kielstein et al. (58) investigated whether it is possible to replace the creatinine test with an SDMA test in clinical labs. They found that considering SDMA measurements as a classic test still suffers from some limitations, such as the high cost, the requirement of extra experiments to support its benefits, and the need for replication in multiple settings. In contrast, the creatinine test is cheaper, easier to perform, and has good sensitivity and selectivity.

\section{Conclusions}

ADMA and SDMA can be presented as valuable combined markers to predict the risk of cardiovascular and kidney diseases. In the current study, the obtained results could not confirm a significant association between ADMA and renal failure parameters, which may indicate that ADMA has no direct effect on urea or creatinine levels in women with low vitamin D levels. In contrast, SDMA in postmenopausal women showed a significant association with urea and creatinine, and thus may be considered as a significant marker of renal dysfunction in elderly populations. However, no significant relationships between ADMA or SDMA and hormonal changes were found either in premenopausal or postmenstrual women with vitamin $D$ insufficiency/deficiency. The limitations of the current study include the collection of blood samples randomly over the year, which may cause a seasonal fluctuation in vitamin D, ADMA, and SDMA levels. Furthermore, the consumption of contraceptives was not taken into consideration during samples collection. Future studies will be needed to investigate ADMA and SDMA levels during the menstrual cycle and to investigate the relationship between these two markers and sex hormones (natural or synthetic) in women suffering from vitamin D insufficiency/deficiency. Moreover, the assessment of NOS inhibitor levels will help in the prevention of endothelial dysfunction, which subsequently suppresses the progression of several diseases and mortality.

\section{Conflict of interest statement}

The author stated that she has no conflicts of interest regarding the publication of this article. 


\section{References}

1. Lindner, A, Charra B, Sherrard DJ, Scribner BH. Accelerated atherosclerosis in prolonged maintenance hemodialysis. N Engl J Med 1974; 290: 697-701.

2. Tarighi S, Najafi M, Hossein-Nezhad A, Ghaedi $H$, Meshkani R, Moradi N, Fadaei R, Kazerouni F, Shanaki M. Association Between Two Common Polymorphisms of Vitamin D Binding Protein and the Risk of Coronary Artery Disease: a Case-Control Study. J Med Biochem 2017; 36; 349-57

3. Vanholder R, Massy Z, Argiles A, Spasovski G, Verbeke F, Lameire N. Chronic kidney disease as cause of cardiovascular morbidity and mortality. Nephrol Dial Transplant 2005; 20: 1048-56.

4. Gungor B. Zeynep, Sipahioglu N, Sonmez H, Ekmekci H, Toprak S, Ayaz G, Bayram Gurel C, Mutlu T, Ulutin T, Sipahioglu F, llerigelen B. Endothelial Dysfunction Markers in Low Cardiovascular Risk Individuals: Comparison of Males and Females. J Med Biochem 2017; 36: 62-72.

5. Pounds LL, Teodorescu VJ. Chronic kidney disease and dialysis access in women. J Vasc Surg 2013; 57(4 Suppl), 49-53S.

6. Goligorsky MS, Noiri E. Duality of nitric oxide in acute renal injury. Semin Nephrol 1999; 19(3): 263-71.

7. Ji H, Zheng W Menini, S Pesce, C Kim, J Wu X, Mulroney $\mathrm{SE}$, Sandberg, K. Female protection in progressive renal disease is associated with estradiol attenuation of superoxide production. Gend Med 2007; 4(1): 56-71.

8. Neugarten, J, Golestaneh, L. Gender and the prevalence and progression of renal disease. Adv Chronic Kidney D. 2013; 20(5): 390-5.

9. Boger, R.H. The emerging role of asymmetric dimethylarginine as a novel cardiovascular risk factor. Cardiovasc. Res. 2003; 59: 824-33.

10. Servillo L. Giovane A, Cautela D, Castaldo D, Balestrieri ML. The methylarginines NMMA, ADMA, and SDMA are ubiquitous constituents of the main vegetables of human nutrition. Nitric oxide: biology and chemistry 2013; 30: 43-8.

11. Pope AJ, Karrupiah K, Kearns PN, Xia Y, Cardounel AJ. Role of dimethylarginine dimethylaminohydrolases in the regulation of endothelial nitric oxide production. J Biol Chem 2009, 284: 35338-47.

12. Wilcox, C.S. Asymmetric dimethylarginine and reactive oxygen species: unwelcome twin visitors to the cardiovascular and kidney disease tables. Hypertension 2012; 59: 375-81.

13. Djordjević BV, Pavlović R, Cosić $\mathrm{V}$, Deljanin-llić $M$, Ristić T, Krstić N, Jevtović-Stoimenov T. High clinical accuracy of asymmetric dimethylarginine and symmetric dimethylarginine in patients with ischemic heart disease. Amino Acids 2012; 43: 2293-300.

14. Celik M, lyisoy A, Celik T, Yilmaz MI, Yuksel UC, Yaman $H$. The relationship between $L$-arginine/ADMA ratio and coronary collateral development in patients with low glomerular filtration rate. Cardiol J 2012; 19: 29-35.

15. Fliser D, Kronenberg F, Kielstein JT, Morath C, BodeBoger SM, Haller H, Ritz E. Asymmetric dimethylarginine and progression of chronic kidney disease: The mild to moderate kidney disease study. J Am Soc Nephrol 2005; 16: 2456-61.
16. Boelaert, J, Schepers, E, Glorieux, G, Eloot, S, Vanholder, $R$, Lynen, F. Determination of Asymmetric and Symmetric Dimethylarginine in Serum from Patients with Chronic Kidney Disease: UPLC-MS/MS versusELISA. Toxins 2016; 8: 149.

17. Boelaert, J, Schepers, E, Glorieux, G, Eloot, S, Vanholder, $\mathrm{R}$, Lynen, F. Determination of Asymmetric and Symmetric Dimethylarginine in Serum from Patients with Chronic Kidney Disease: UPLC-MS/MS versusELISA. Toxins 2016; 8: 149.

18. Kielstein JT, Fliser D, Veldink H. Asymmetric dimethylarginine and symmetric dimethylarginine: Axis of evil or useful alliance? Semin Dial 2009; 22: 346-50.

19. Kahraman A, Mutlu E, Alda M. ADMA, SDMA and Larginine may be Novel Targets in Pharmacotherapy for Complications due to Cardiopulmonary Bypass. J Med Biochem 2017; 36: 8-17.

20. Ngo DT, Sverdlov AL, McNeil JJ, Horowitz JD. Does Vitamin D Modulate Asymmetric Dimethylarginine and C-Reactive Protein Concentrations? Am J Med 2010; $123,335-41$.

21. Choi HR, Lee SW, Yeom $H$, Jeon $D H$, Kim HC, Youm $Y$. Association between vitamin $D$ status and asymmetric dimethylarginine (ADMA) concentration in the Korean elderly population. Maturitas 2017, 102, 13-17.

22. Bednarek-Skublewska A, Smoleń A, Jaroszyński $A$, Załuska W, Ksiazek A. Effects of vitamin D3 on selected biochemical parameters of nutritional status, inflammation, and cardiovascular disease in patients undergoing long-term hemodialysis. Pol Arch Med Wewn 2010; 120: 167-74.

23. Kim C, Cushman M, Kleindorfer D, Lisabeth L, Redberg RF, Safford MM. A review of the relationships between endogenous sex steroids and incident ischemic stroke and coronary heart disease events. Curr Cardiol Rev 2015; 11(3): 252-60.

24. Mehrotra R, Kermah D, Budoff M, Salusky IB, Mao SS, Gao YL, Takasu J, Alder S, Norris K. Hypovitaminosis D in Chronic Kidney Disease. CJASN 2008; 3(4): 1144-51.

25. Satirapoj B, Limwannata P, Chaiprasert A, Supasyndh O, Choovichian P. Vitamin $D$ insufficiency and deficiency with stages of chronic kidney disease in an Asian population. BMC Nephrol 2013; 14: 206.

26. Bode Böger SM, Scalera F, Kielstein JT, Martens Lobenhoffer J, Breithardt G, Fobker M, Reinecke H. Symmetrical dimethylarginine: a new combined parameter for renal function and extent of coronary artery disease. J Am Soc Nephrol 2006; 17: 1128-34.

27. Schepers E, Speer T, Bode-Boger SM, Fliser D, Kielstein JT. Dimethylarginines ADMA and SDMA: the real water-soluble small toxins? Semin Nephrol 2014; 34(2): 97-105.

28. Schulze F, Maas R, Freese R, Schwedhelm E, Silberhorn $\mathrm{E}$, Böger $\mathrm{RH}$. Determination of a reference value for $\mathrm{NG}$, NG-dimethyl-L-arginine in 500 subjects. Eur J Clin Invest 2005, 35, 622-6.

29. Damiati S, Khoja S. Serum concentrations of asymmetric dimethyl-L-arginine in diabetes mellitus and hyperlipidemia. Clin Exp Med J 2009; 3: 443-52. 
30. Rocca WA, Grossardt BR, Miller VM, Schuster LT, Brown RD. Premature menopause or early menopause and risk of ischemic stroke. Menopause 2012; 19(3): 272-7.

31. North American Menopause Society. Menopause Practice: A Clinician's Guide. 4. Cleveland, $\mathrm{OH}$ : North American Menopause Society; 2010.

32. Tanahashi K, Akazawa N, Miyaki A, Choi Y, Ra SG, Matsubara T, Kumagai H, Oikawa S, Miyauchi T, Maeda S. Plasma ADMA concentrations associate with aerobic fitness in postmenopausal women. Life Sci 2014; 108: 30-3.

33. Verhoeven MO, Hemelaar $M$, van der Mooren MJ, Kenemans $\mathrm{P}$, Teerlink T. Oral, more than transdermal, oestrogen therapy lowers asymmetric dimethylarginine in healthy postmenopausal women: a randomized, placebo-controlled study. J Internal Med 2006; 259: 199-208.

34. Holden DP, Cartwright JE, Nussey SS, Whitley GS. Estrogen stimulates dimethylarginine dimethylaminohydrolase activity and the metabolism of asymmetric dimethylarginine. Circulation 2003; 108: 1575-80.

35. Valtonen P, Punnonen K, Saarelainen $H$, Heiskanen N, Raitakari $O$, et al. ADMA concentration changes across the menstrual cycle and during oral contraceptive use: the Cardiovascular Risk in Young Finns Study. Euro J Endocrinology 2010; 162: 259-65.

36. Campesi I, Occhioni S, Tonolo G, Cherchi S, Basili S, Carru $C$, et al. Ageing/menopausal status in healthy women and ageing in healthy men differently affect cardiometabolic parameters. Int J Med Sci 2016; 13(2): 124-32.

37. Cooke JP. ADMA: its role in vascular disease. Vasc Med 2005; 10: S11-7. 11.

38. Damiati S, Khoja S. Serum asymmetric dimethyl -L-argnine in renal failure patients living in Jeddah region, Saudi Arabia. Trends in Medical Research 2011; 6: 14-22.

39. Selley ML. Increased concentrations of homocysteine and asymmetric dimethylarginine and decreased concentrations of nitric oxide in the plasma of patients with Alzheimer's disease. Neurobiol Aging 2003; 24: 903-7.

40. Krzyzanowska K, Mittermayer F, Kopp HP, Wolzt M, Schernthaner $\mathrm{G}$. Weight loss reduces circulating asymmetrical dimethylarginine concentrations in morbidly obese women. J Clin Endocrinol Metab 2004; 89: 6277-81.

41. Damiati S. Serum Levels of Asymmetric and Symmetric Dimethylarginine in Woman with Vitamin D Deficiency and History of Pregnancy Loss - A Pilot Study. J Med Biochem 2018; 37.

42. Maaty MA, Hassanein SI, Hanafi RS. Insights on vitamin D's role in cardiovascular disease: investigating the association of 25-hydroxyvitamin $D$ with the dimethylated arginines J Nutr Sci Vitaminol 2013; 59(3): 172-7.

43. Ngo DT, Sverdlov AL, McNeil JJ, Horowitz JD. Does vitamin $D$ modulate asymmetric dimethylarginine and $\mathrm{C}$ reactive protein concentrations? Am J Med 2010; 123 (4): 335-41.

44. Bedford MT, Richard S. Arginine methylation an emerging regulator of protein function. Mol Cell 2005; 18: 263-72.
45. Chitalia N, Recio-Mayoral A, Kaski JC, Banerjee D. Vitamin D deficiency and endothelial dysfunction in nondialysis chronic kidney disease patients. Atheroscler 2012; 220: 265-8.

46. Delles C, Jacobi J, John S, Fleischmann I, Schmieder RE. Effects of enalapril and eprosartan on the renal vascular nitric oxide system in human essential hypertension. Kidney Int 2002; 61: 1462-8.

47. Ito A, Egashira K, Narishige T, Muramatsu K, Takeshita A. Renin-angiotensin system is involved in the mechanism of increased serum asymmetric dimethylarginine in essential hypertension. Jpn Circ J 2001; 65: 775-8.

48. Napoli R, Biondi B, Guardasole V, Matarazzo M, Pardo F, Angelini V, Fazio S, Saccà L. Impact of hyperthyroidism and its correction on vascular reactivity in humans. Circulation 2001; 104: 3076-80.

49. Oliva-Damaso E, Oliva-Damaso N, Rodriguez-Esparragon F, Payan J, Marañes A, Parodis Y, et al. Asymmetric Dimethylarginine (ADMA) Levels Are Lower in Hemodialysis Patients Treated With Paricalcitol. Kidney Int Reports 2017; 2: 165-71.

50. Sugden J, Davies JI, Witham MD, Morris AD, Struthers $A D$. Vitamin $D$ improves endothelial function in patients with Type 2 diabetes mellitus and low vitamin D levels. Diabet Med 2008; 25: 320-5.

51. Pai $A B$. Changes in plasma levels of asymmetric dimethylarginine in chronic kidney disease patients treated for 8 weeks with the vitamin D receptor agonist paricalcitol. J Res Dev 2015; 3: 129.

52. Schwedhelm E, Böger RH. The role of asymmetric and symmetric dimethylarginines in renal disease. Nature Rev Nephrol 2011; 7 (5): 275-85

53. Kielstein JT, Salpeter SR, Bode-Boeger SM, Cooke JP, Fliser D. Symmetric dimethylarginine (SDMA) as endogenous marker of renal function-a meta-analysis. Neph Dialy Transplant 2006; 21: 2446-51.

54. Al Banchaabouchi M, Marescau B, Possemiers I, D'Hooge R, Levillain O, De Deyn PP. NG, NG-dimethylarginine and NG, NG-dimethylarginine in renal insufficiency. Pflugers Arch 2000; 439: 524-31.

55. Carello KA, Whitesall SE, Lloyd MC, Billecke SS, D'Alecy, LG. Asymmetrical dimethylarginine plasma clearance persists after acute total nephrectomy in rats. Am J Physiol Heart Circ Physiol 2006; 290: H209-H216.

56. Tojo A, Welch WJ, Bremer V, Kimoto $M$, Kimura $K$, Omata M, Ogawa T, Vallance P, Wilcox CS. Colocalization of demethylating enzymes and NOS and functional effects of methylarginines in rat kidney. Kidney Int 1997; 52: 1593-601.

57. Closs El, Basha FZ, Habermeier A, Forstermann U. Interference of $\mathrm{L}$-arginine analogues with $\mathrm{L}$-arginine transport mediated by the $y+$ carrier hCAT-2B. Nitric Oxide 1997; 1: 65-73.

58. Kielstein JT, Martens-Lobenhoffer J, Vollmer S, BodeBoger SM. L-Arginine, ADMA, SDMA, creatinine, MDRD formula-detour to renal function testing. J Nephrol 2008; 21: 963-5. 